\title{
Brick Lane
}

Monica Ali

London: Doubleday, 2003. 369 pages.

Monica Ali's debut novel Brick Lane has been met with critical acclaim. Not only was Ali selected as one of Granta's Best Young British Novelists, her novel was short-listed for the Man Booker Prize. Brick Lane centers on the life of a young Bengali Muslim woman, Nazneen, who moves to London in order to live with her new husband, Chanu. At the beginning of the novel, Nazneen is a devout but docile and uninspiring character. By the end of the novel, she has journeyed "towards self-realisation," had an affair, separated from her husband, and decided to bring up her two daughters alone.

Much of the praise that Brick Lane has elicited focuses on its "authenticity." Reputable critics have praised Ali for her "timely insights," and her novel has been judged to offer a "terrifically subtle portrait" of a Muslim marriage and provide "an insight into a religion that people often find confusing." Articles that commend Ali for her "honest" and "precisely observed" descriptions of Muslims attest to her perceived status as a "native informant." Although literary critics frequently warn that texts should not be read as transparent mediums through which you can drag "the real," this is frequently forgotten when the author is someone from an ethnic or religious minority. Those critical of the current trend to read Brick Lane as a "window" through which to view the Muslim "Other" have been dismissed with alarming efficiency. Despite recent concurrent developments in literary theory, challenges to this assumed "transparency" have been dismissed as the opinions of "mullahs," "Islamic fundamentalists," or people who have "probably never read the book."

Unfortunately, cliché-ridden characterization and clumsy stylistic weaknesses have been overlooked in the rush to applaud Ali for her "fascinating" depiction of what has been referred to as a hitherto "invisible" Muslim community. So why should we be concerned that her Muslim characters have been judged to be authentic? One could look at the dark hole that is Bangladesh, in which, according to the novel, Muslim men do little else but beat, pimp, or rape women. Or, one could focus on the central female character's journey toward "self-realisation." This journey panders to a 1960s style of western feminism. The fatalistic and passive Nazneen, having spent years praying in a "drugged"-like fashion and tending to her 
husband's corns and nasal hair, eventually becomes strong and independent. In order to do so, she has an affair, listens to a bit of pop music, and goes ice-skating.

If only the plot had been more daring and provocative. Nazneen could have insisted on learning English at college with Razia before heading off into a glittering teaching career. She could have helped one of her daughters become the first "hijabed" bus driver or car mechanic in Tower Hamlets. Or, she could have just found out what her rights as a Muslim woman actually were. Having discovered that the Prophet Muhammad helped with the housework, mended his own shoes, and defended women's rights, Nazneen could at least have avoided her corn-duties.

Brick Lane has been welcomed precisely because it fails to challenge established prejudices about Muslims. The women are mostly bullied by their husbands and consider their marriages to be "good" if they are not "beaten." Brick Lane perpetuates the myth that Muslim women can become assertive and confident only by becoming more westernized and less Muslim. Regrettably, many would consider the story of a Muslim woman who discovers and starts exercizing her Islamic rights as "unconvincing." That Nazneen, a passive and weak character who is infuriatingly unwilling to challenge her husband in matters of trivia, is happy to engage in an illic it sexual relationship that she believes will risk not only her husband's anger but eternal damnation is considered far more convincing. Although many feminist critics congratulate Ali for writing the story of a Muslim woman who finds "her proper place in the world," it is a shame that none question the assumption that a Muslim woman's "proper place" can only be found in the full embrace of western liberalism.

Ali's "Muslim meetings" constitute another area that has been commended for its accuracy. These meetings are full of stock Muslim characters that owe much to the unflattering portrayal of the "Arabs" populating Disney and Hollywood productions. For example, the Bengali Islamist character (who rivals Nazneen's lover at these meetings) is "Arabised" in Hollywood fashion due to his political stance. This character, who is referred to only as "the Questioner," has the "dangerous face of an enthusiast" and is a deathly skeletal figure. "Consumed by passion," his clothes hang from his body like an "unnecessary extravagance." His "flesh" is also "unnecessary," and the "only extravagance" is "his nose, which was large." Serious points made about suffering in the Muslim world are undermined by the fact that they are voiced by this unsavory caricature. 
The Questioner is far from being the only figure of ridicule at these meetings. The "recently imported" imam hardly inspires respect. The narrative voice centers on his hypocrisy: He does not let his "little conference on sharia interfere with his consumption of a very large, lavishly glazed pastry." His physical presence is equally unimpressive: wearing a pair of women's shoes, he repeatedly wets and licks his lips, "has no idea what is going on," and is "duly elected as Spiritual Leader." Unfortunately these passages, clearly loaded with caricature, melodrama, and satire, have been read as "realist" in style and "authentic" in content.

Muslim concerns about representation cannot be dismissed by the argument that Brick Lane "is only a fiction" while critics continue to praise Ali for her "social observations" and "private insights." That reviewers have been so quick to judge her unsympathetic "Muslim" characters as "precisely observed" tells us more about the existing prejudices than about the novel's literary worth. Ali does not "capture" the "experience" of Muslim women in Britain; she just mobilizes familiar clichés that many are tired of hearing.

Wendy O'Shea Meddour

Tutor and Fellow, Dept. of English Literature

St. Hilda's College, Oxford University Oxford, United Kindgom 